\title{
Fisheries, life-history and conservation status of the catfish pirá Conorhynchos conirostris (Ostariophysi: Siluriformes) in Brazil
}

\author{
Alexandre Lima Godinho ${ }^{1}$ and Hugo Pereira Godinho ${ }^{2}$
}

Pirá, Conorhynchos conirostris (Valenciennes, 1840), a large migratory catfish endemic to the São Francisco River (SFR), is listed as threatened in the red lists of both Brazil and the state of Minas Gerais. Although fishing for pirá has been prohibited, it is still an important fishery resource, particularly in the middle SFR. We used historical and current occurrence and abundance data regarding pirá to determine if it meets the IUCN criteria of a threatened species. Pirá occurs in the main course of the SFR as well as in its major tributaries. Unlike the most well-known migratory fishes of the SFR, pirá does not use floodplain lakes as nurseries. In the first half of the $20^{\text {th }}$ century, pirá occurred from the upper to the lower SFR. Currently, it is most abundant in the middle SFR, and is rare in the upper SFR and even rarer in the sub-middle SFR. Pirá has not been captured in the lower SFR since around the mid-1980's. Despite the reduction in its geographic distribution, we did not find evidence to justify considering pirá as threatened. Thus, we recommend that it be removed from the red lists of Brazil and the state of Minas Gerais.

Keywords: IUCN, Red list, São Francisco River, Threatened fish.

Pirá, Conorhynchos conirostris (Valenciennes, 1840), um grande siluriforme migrador endêmico do rio São Francisco (RSF), está incluído como ameaçado nas listas vermelhas do Brasil e do estado de Minas Gerais. Embora sua pesca esteja proibida, ele ainda é recurso pesqueiro importante, particularmente no médio RSF. Utilizamos dados históricos e atuais de ocorrência e abundância do pirá para determinar se ele atende aos critérios da UICN para ser classificado como ameaçado. Pirá ocorre na calha do RSF, bem como em seus principais afluentes. Ao contrário dos peixes migradores mais conhecidos do RSF, ele não usa lagoas das várzeas como berçários. Na primeira metade do século 20 , pirá costumava ocorrer do alto ao baixo RSF. Atualmente, ele é mais abundante no médio RSF. A espécie é rara no alto RSF e parece ainda mais rara no sub-médio RSF. O pirá não é capturado no baixo RSF desde cerca da metade da década de 1980. Apesar da redução na distribuição geográfica, não encontramos evidências para classificar o pirá como espécie ameaçada e, portanto, recomendamos que ele seja removido das listas vermelhas do Brasil e do estado de Minas Gerais.

Palavras-chave: Lista vermelha, Peixe ameaçado, Rio São Francisco, UICN.

\section{Introduction}

Pirá, Conorhynchos conirostris (Valenciennes, 1840), is a large long-nosed member of the order Siluriformes (Fig. 1) that is endemic to the São Francisco River (SFR) basin in Brazil. It is the third largest fish of the SFR basin, reaching $100 \mathrm{~cm}$ in total length and $13 \mathrm{~kg}$ in body weight (Sato, 1999). Pirá is migratory (Sato, Godinho, 2003), and placed in Balon's (1975) non-guarder, open substratrum, pelagophil reproductive guild. Its spawning and nursery grounds remain largely unknown.
The SFR basin has witnessed a remarkable decline in its fishery in the last few decades. Fishery yields reduced from $16 \mathrm{~kg}$. fisher ${ }^{-1}$ day $^{-1}$ in the mid 1970's (Superintendência de Desenvolvimento da Pesca, Companhia de Desenvolvimento do Vale do Rio São Francisco, 1980) to $12 \mathrm{~kg}$. fisher ${ }^{-1}$.day $^{-1}$ in the late 1980 's, and to $3 \mathrm{~kg}$. fisher ${ }^{-1}$.day ${ }^{-1}$ in the late 1990's (Godinho et al., 2007). In 2008-2009, fishery catches returned to values closed to those of the late 1980's following two consecutive years of significant river floods (personal data).

${ }^{1}$ Centro de Transposição de Peixes, Universidade Federal de Minas Gerais, 31270-901 Belo Horizonte, MG, Brazil. godinhoal@gmail.com, Dhttps://orcid.org/0000-0003-0675-9256 (corresponding author)

${ }^{2}$ Departamento de Morfologia, Instituto de Ciências Biológicas, Universidade Federal de Minas Gerais, $31270-901$ Belo Horizonte, MG, Brazil.hgodinho@ufmg.br 


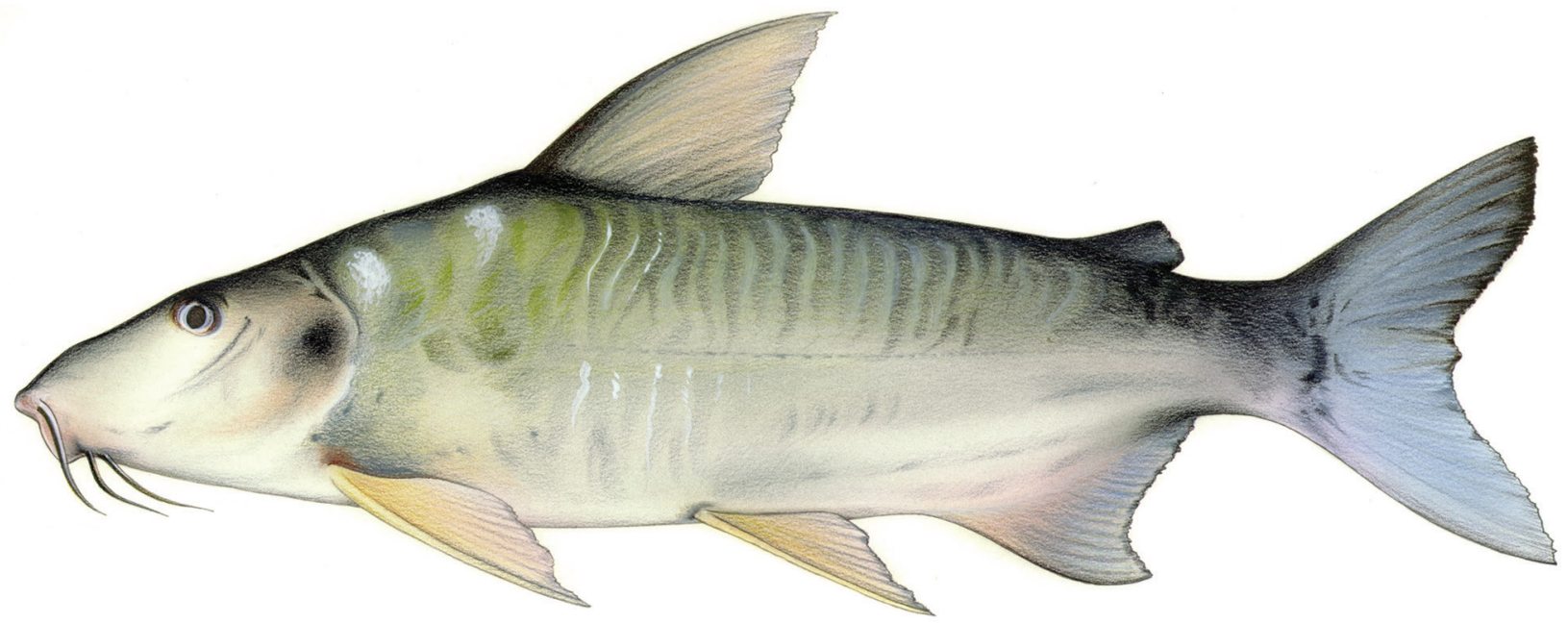

Fig. 1. Conorhynchos conirostris, pirá (drawing by Paulo Henrique Fiote).

Pirá has been a substantial component of artisanal fisheries in the middle SFR (Godinho et al., 1997). Nevertheless, it is listed as threatened in the red lists of Brazil and the state of Minas Gerais. The criteria for inclusion in both lists considered reductions in population size and geographic distribution. Prohibition of fishing for pirá, as a protected species, has received criticism from those who fish in the middle SFR, and who claim pirá is still relatively abundant.

Herein, we use original and secondary data to assess the spatio-temporal occurrence and abundance of pirá in the SFR basin. We used this information to evaluate if pirá indeed qualifies for red-listing, and discuss its reproductive strategy based on patterns of temporal abundance and habitat use.

\section{Material and Methods}

Study area. The SFR basin is the fourth largest river basin in South America. It covers $631,133 \mathrm{~km}^{2}$, and encompasses $7.4 \%$ of Brazilian territory (Fig. 2). The SFR runs northeasterly for $2,814 \mathrm{~km}$ (Silva et al., 2003), wholly within Brazil. We recognize the following regions of the SFR: upper SFR (from headwaters to Três Marias Dam, $18^{\circ} 12^{\prime} 47^{\prime \prime} \mathrm{S} 45^{\circ} 16^{\prime} 16^{\prime} \mathrm{W}$ ), middle SFR (from Três Marias Dam to Sobradinho Dam, 09²5'48"S 40'49'29”W), sub-middle SFR (from Sobradinho Dam to Xingó Dam, 09³7'65"S 37 47'30"W) and lower SFR (from Xingó Dam to the mouth, 10'30'11"S $36^{\circ} 23^{\prime} 46^{\prime \prime} \mathrm{W}$ ).

There are seven large dams on the SFR. The year of the start of their operations (Comitê Brasileiro de Grandes Barragens, 1982) and the river $\mathrm{km}(\mathrm{rkm})$ of their locations (personal data) are: Três Marias (1961, rkm 2,133), Sobradinho (1979, rkm 750), Itaparica (1986, rkm 305), Moxotó (1974, rkm 275), Paulo Afonso I (1954, rkm 270), Paulo Afonso IV (1979, rkm 268) and Xingó (1994, rkm 210). Três Marias Dam is the only dam on the main river course in the 2,064 rkm of the upper and middle regions of SFR; all other dams are in the $750 \mathrm{rkm}$ of the sub-middle and lower regions of the SFR. All of these larger dams are primarily for hydropower, while there are a few dozen smaller dams for power generation or water supply in tributaries of the SFR.

Occurrence and abundance. We obtained data for 930 pirá captured by artisanal and sport fishers operating in the middle SFR. We gathered data from artisanal fishers from three municipalities (Três Marias: 18 12'14"'S

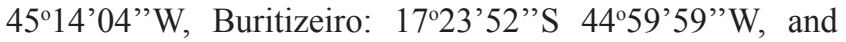
Januária: $15^{\circ} 29^{\prime} 65^{\prime \prime} \mathrm{S} 44^{\circ} 21^{\prime} 06^{\prime \prime} \mathrm{W}$ ) and from anglers in two municipalities (Três Marias and Ibiaí: 16049'83"S $44^{\circ} 55^{\prime} 70^{\prime \prime}$ W). We collected data from January to December 1999 in Buritizeiro, and from March 1999 to May 2000 at all other sites. At Três Marias, Buritizeiro and Ibiaí, we gathered data at landing sites, whereas we visited artisanal fisher camps in Januária.

We also gathered data from pirá artisanal fisheries along a 152-rkm stretch of the middle SFR between the municipalities of Pirapora $\left(17^{\circ} 19^{\prime} 36^{\prime \prime} \mathrm{S} \quad 44^{\circ} 56^{\prime} 01^{\prime \prime} \mathrm{W}\right)$

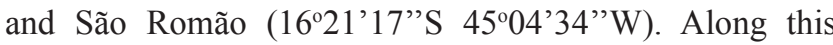
stretch, fishing was performed by the crew of a fishing boat belonging to the artisanal fishers association of Pirapora. We collected data during 3-5 consecutive days per month during fishing trips in the years of 1987 (July to December, except September), 1999 (March to November) and 20082009 (August to July, except March and May). The distance the boat navigated downstream during fishing trips ranged from 25-122 rkm. In 1987, the crew included 4-5 fishing duos, while in 1999 and 2008-2009 it included 2-4 fishing duos. Occasionally, a duo turned into a trio. Each duo/trio used a 5-m long boat to fish. In 1987, they mainly used wood boats and oars, but in 1999 they also used duralumin boats equipped with $\leq 15 \mathrm{hp}$ outboard motors. In 2008-2009, they used only duralumin boats with $15-25 \mathrm{hp}$ outboard motors. During the fishing trips, we did not interfere in any working aspect of the fishers (e.g., fishing time, fishing spot, fishing gear, etc.) that could potentially influence their fishing routine. A voucher specimen was deposited in the fish collection of the Federal University of Minas Gerais under the number ICT-UFMG 2869. 


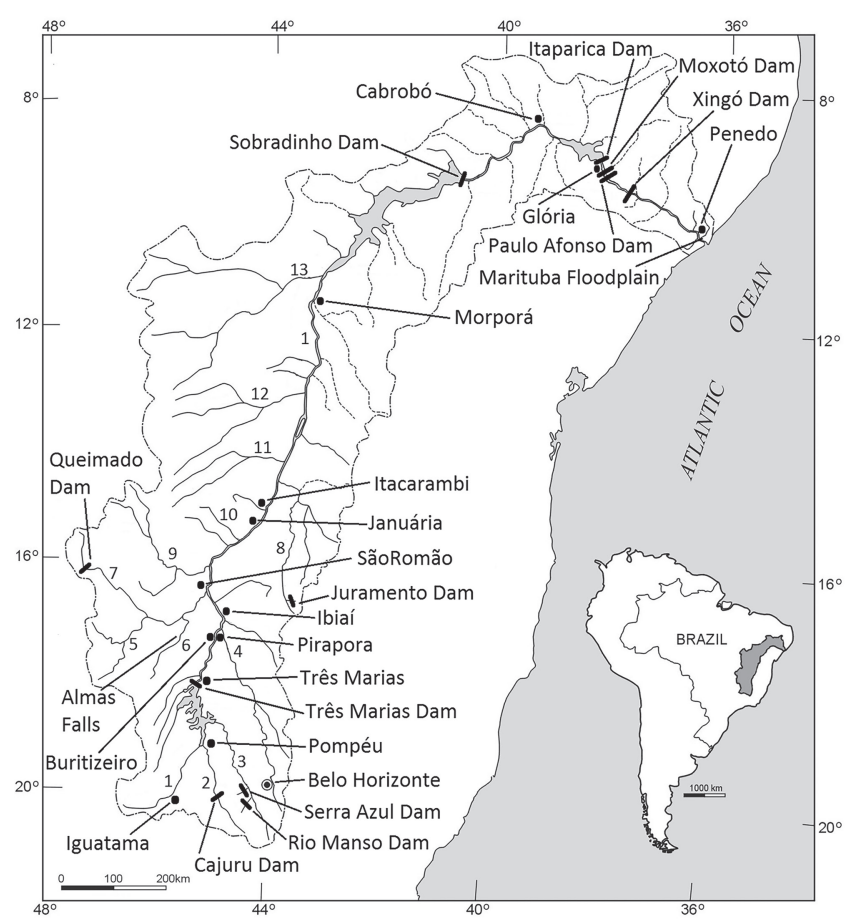

Fig. 2. Map of São Francisco River basin showing major rivers and all municipalities and dams cited in the text. $(1=$ São Francisco River, 2 = Pará River, 3 = Paraopeba River, $4=$ Velhas River, $5=$ Paracatu River, $6=$ Sono River, $7=$ Preto River, $8=$ Verde Grande River, $9=$ Urucuia River, 10 $=$ Pandeiros River, $11=$ Carinhanha River, $12=$ Corrente River, and $13=$ Grande River).

We recorded total length (TL) and body weight (BW) of all pirá, except for those captured at Januária for which we recorded biomass and number captured per fisher per day $^{-1}$ instead. We determined sex of all pirá except those at Três Marias, Ibiaí and Januária. For each fishing site and fishing category (artisanal and sport), we estimated the catch per unit effort in number ( $\mathrm{CPUE}_{\mathrm{n}}$ ) and biomass $\left(\mathrm{CPUE}_{\mathrm{b}}\right)$ as, respectively, the number or biomass of pirá caught per fisher per day regardless of the number of hours spent fishing by each fisher.

We used data available in scientific papers, books and reports as well as our personal data to determine historical ( $>10$ years old) and recent $(\leq 10$ years old) abundance trends and habitat preferences of pirá as of 2010 . We also interviewed heads of artisanal fishers associations in all SFR regions regarding the presence/absence and abundance trends of pirá in their respective fishing areas.

Catch statistics. We used frequency distributions to compare $\mathrm{CPUE}_{\mathrm{n}}$ among fishing sites and between fishing categories (artisanal versus sport) because $\mathrm{CPUE}_{\mathrm{n}}$ was highly negatively skewed due to the large number of zeros. We tested for differences in BW among fishing sites using the Kruskal-Wallis test, and between fishing categories using the Wilcoxon test. We used these nonparametric tests since BW was not normally distributed even after transformations. We used the Dunn test for nonparametric multiple comparisons. We also tested for differences in the mean BW of pirá captured by the fishing boat of the artisanal fishers association of Pirapora among the years of 1987, 1999 and 2008-2009 using ANOVA followed by Tukey-Kramer multiple comparison test. For the ANOVA, we $\log$ transformed BW of pirá to achieve normality. For all tests, we used a 0.05 level of significance. We used SAS for all data and statistical analyses except for the Dunn test, for which we used BioEstat 5.0 (Ayres et al., 2007).

Conservation status. We evaluated each International Union for Conservation of Nature (IUCN) criterion used to justify the inclusion of pirá in the 2004 and 2014 red lists of Brazil and in the 2010 red list of the state of Minas Gerais. We based most of our evaluation on the data of the present study and those in the guidelines provided by IUCN (2001) and from the Instituto Chico Mendes de Biodiversidade (ICMBio, 2013). We also used data from the literature to support our evaluation.

\section{Results}

Occurrence. Documents from the first half of the $20^{\text {th }}$ century mentioned the occurrence of pirá in all four regions of the main course of the SFR. Recent records included all these regions except the lower SFR where, according to Instituto Xingó (2003), the species has not been captured since around the mid-1980's. Recent records have also shown pirá to be present in most of the riverside municipalities of the middle SFR, mainly in the state of Minas Gerais. Although rare, pirá is still being recorded from the upper SFR.

Pirá has been recorded in the major tributaries of the middle (Urucuia, Paracatú, Velhas rivers) and upper (Paraopeba River) SFR. It has been recorded in the first $133 \mathrm{rkm}$ of the Sono River (a tributary of the lower Paracatu River), but not in the Preto River (a tributary of the upper Paracatu River). In the Velhas River, although not abundant, pirá used to occur from the mouth up to, at least, its middle segment; today pirá seems to be restricted to the stretch near the mouth. Pirá has been recorded in the lower Paraopeba River, but not in the upper segment. There were no records of pirá in the Pandeiros and Juramento rivers, both mid-sized tributaries of the middle SFR. We did not find records of pirá in tributaries of the sub-middle and lower SFR.

Among the main course reservoirs, pirá was rare in Três Marias Reservoir. In Sobradinho Reservoir, pirá accounted for $1.3 \%$ of the landings in 1982, three years after its filling, but now they are rarely captured by artisanal fishers. Pirá has not been found in Xingó Reservoir. We found no information on presence/absence of pirá in other main course reservoirs (i.e., Itaparica, Moxotó, Paulo Afonso I and Paulo Afonso IV). There were no records of pirá in reservoirs of the upper and middle SFR tributaries (i.e., Cajuru, Rio Manso, Serra Azul, Juramento and Queimado reservoirs). 
We collected information regarding the presence/ absence of pirá from 60 floodplain lakes: nine in the upper SFR (between the municipalities of Iguatama and Pompéu, in the state of Minas Gerais), four in the middle SFR (in the municipalities of Itacarambi, Minas Gerais and Morpora, in the state of Bahia), 25 in the sub-middle SFR (between the municipalities of Cabrobó in the state of Pernambuco and Glória in the state of Bahia) and 22 in the Marituba floodplain (in the state of Alagoas) located in the lower region. Pirá was absent from all of these floodplain lakes except Lagoa Grande in Morporá, where it was recorded in the mid $20^{\text {th }}$ century. We found no further information regarding the presence of pirá in Lagoa Grande.

Abundance. During 1998-2000, pirá ranked from $2^{\text {nd }}$ to $7^{\text {th }}$ in artisanal fisheries in the middle SFR, but ranked lower in sport fisheries (Tab. 1). In the lower SFR in 1940, pirá ranked $13^{\text {th }}$ among the landings of the artisanal fishers association of Penedo.

Tab. 1. Biomass and number of Conorhynchos conirostris caught in artisanal and sport fisheries at various sites in the middle São Francisco River, from 1998-2000. Personal data for all species are also presented.

\begin{tabular}{|c|c|c|c|c|c|c|}
\hline \multirow[b]{2}{*}{ Site } & \multicolumn{3}{|c|}{ Biomass (kg) } & \multicolumn{3}{|c|}{ Number of fish } \\
\hline & $\begin{array}{c}\text { All } \\
\text { species }\end{array}$ & pirá & $\begin{array}{l}\text { pirá } \\
\text { rank }\end{array}$ & $\begin{array}{c}\text { All } \\
\text { species }\end{array}$ & pirá & $\begin{array}{l}\text { pirá } \\
\text { rank }\end{array}$ \\
\hline \multicolumn{7}{|c|}{ Artisanal fisheries } \\
\hline Três Marias & $2,278.2$ & 32.8 & $7^{\text {th }}$ & 1,467 & 25 & $7^{\text {th }}$ \\
\hline Buritizeiro & $2,354.9$ & 195.8 & $4^{\text {th }}$ & 2,083 & 298 & $2^{\text {nd }}$ \\
\hline Pirapora-São Romão & 531.3 & 60.2 & $4^{\text {th }}$ & 317 & 33 & $2^{\text {nd }}$ \\
\hline Januária & $10,209.9$ & 865.6 & $4^{\text {th }}$ & 12,446 & 402 & $3^{\text {rd }}$ \\
\hline \multicolumn{7}{|c|}{ Sport fisheries } \\
\hline Três Marias & 768.3 & 2.1 & $9^{\text {th }}$ & 480 & 2 & $10^{\text {th }}$ \\
\hline Ibiaí & $1,671.3$ & 41.1 & $8^{\text {th }}$ & 2,965 & 29 & $11^{\text {th }}$ \\
\hline
\end{tabular}

Pirá was one of the most captured species by the fishing boat of the artisanal fishers association of Pirapora, ranking between $2^{\text {nd }}$ and $5^{\text {th }}(\mathrm{Tab} .2)$. The $\mathrm{CPUE}_{\mathrm{b}}$ and $\mathrm{CPUE}_{\mathrm{n}}$ for pirá were similar among the years of 1987, 1999 and 2008-2009. Mean BW of pirá was greater in 1987 than in 1999 and 2008-2009.

Tab. 2. Biomass, number, $\mathrm{CPUE}_{\mathrm{b}}\left(\mathrm{kg} \cdot \mathrm{fisher}^{-1} \cdot \mathrm{day}^{-1}\right)$, $\mathrm{CPUE}_{\mathrm{n}}$ (number of fish.fisher ${ }^{-1}$ day $^{-1}$ ), and body weight of Conorhynchos conirostris captured by the fishing boat of the artisanal fishers association of Pirapora in 1987, 1999, and 2008-2009. ${ }^{\dagger}$ Different superscripts indicate significant differences (Tukey-Kramer multiple comparison test).

\begin{tabular}{cccccc}
\hline Year & $\begin{array}{c}\text { Biomass } \\
(\mathrm{kg})\end{array}$ & $\begin{array}{c}\text { Number } \\
\text { of pirá }\end{array}$ & $\begin{array}{c}\mathrm{CPUE}_{\mathrm{b}} \\
(\text { rank })\end{array}$ & $\begin{array}{c}\mathrm{CPUE}_{\mathrm{n}} \\
(\mathrm{rank})\end{array}$ & $\begin{array}{c}\text { Body weight } \\
(\mathrm{mean} \pm \mathrm{sd})^{\dagger}\end{array}$ \\
\hline 1987 & 96.2 & 29 & $0.46\left(3^{\text {rd }}\right)$ & $0.14\left(3^{\text {rd }}\right)$ & $3.3 \pm 2.0^{\mathrm{a}}$ \\
1999 & 60.2 & 33 & $0.37\left(4^{\text {th }}\right)$ & $0.20\left(2^{\text {nd }}\right)$ & $1.8 \pm 0.9^{\mathrm{b}}$ \\
$2008-2009$ & 90.8 & 53 & $0.34\left(5^{\text {th }}\right)$ & $0.20\left(5^{\text {th }}\right)$ & $1.7 \pm 0.8^{\mathrm{b}}$ \\
\hline
\end{tabular}

Days with zero pirá captures $\left(\mathrm{CPUE}_{\mathrm{n}}=0\right)$ were the most common finding for all fishing sites (Fig. 3) with the highest values being at Ibiaí (sport fishing) and Três Marias (for both fishing categories). Days with $\mathrm{CPUE}_{\mathrm{n}}$ higher than 2 fish. fisher ${ }^{-1}$.day ${ }^{-1}$ occurred only in the artisanal fishing sites of Buritizeiro and Pirapora-São Romão.
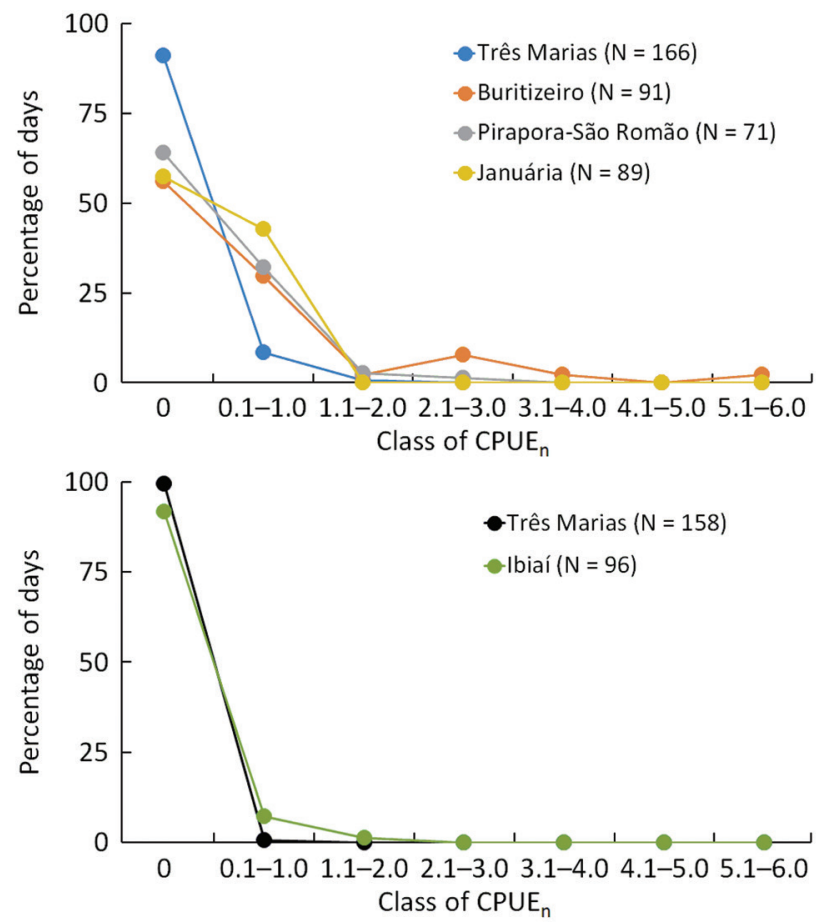

Fig. 3. Percentage of days with Conorhynchos conirostris captures per $\mathrm{CPUE}_{\mathrm{n}}$ class by fishing site for artisanal (top panel) and sport (bottom panel) fishing. $\left(\mathrm{CPUE}_{\mathrm{n}}=0\right.$ corresponds to days with zero pirá captured; $\mathrm{N}=$ number of sampling days; the Pirapora-São Romão fishing site does not include data from 1987).

Body size. We recorded pirá ranging 18.3-92.0 cm TL and $0.8-9.0 \mathrm{~kg} \mathrm{BW}(\mathrm{N}=429)$. Artisanal fishers captured pirá with greater $\mathrm{BW}$ than sport fishers (Wilcoxon test: $P<0.001$ ). Pirá BW also differed among artisanal fishing sites (KruskalWallis test: $P<0.001$ ), with the smallest pirá being captured at Buritizeiro and the largest at Pirapora-São Romão (Dunn test).

\section{Discussion}

Occurrence, abundance and fishing. Data on occurrence and abundance showed that pirá prefers the flowing water of rivers over the standing water of reservoirs, and that it inhabits the main course of SFR and its major tributaries. In the main course, pirá historically occurred from the upper region to the mouth. However, we were unable to determine the upstream limit of its historical and recent geographic distribution. Occurrence of pirá in the main course has been reduced to the 1,182 rkm of the middle SFR between Três Marias Dam and Sobradinho Reservoir. The Paracatú River is the most important tributary habitat for pirá. 
Pirá abundance does not seem to be linked to river flood, as it is for other migratory fishes of SFR. In general, the fishing boat of the artisanal fishers association of Pirapora primarily targeted migratory fishes. The $75 \%$ reduction in migratory fish $C P U E_{b}$ from late 1987 to late 1997 was most likely due to the absence of significant floods during this period (Godinho et al., 2007). In 2008-2009, the $C P U E_{b}$ returned to values close to those of 1987 after two consecutive years of significant floods (personal data). Abundance of young migratory fishes also increased in the SFR after two consecutive years of significant floods (Prado et al., 2017). Unlike other SFR migratory fishes, the CPUE of pirá did not show relevant temporal changes from late 1980 to late 2000.

The relevance of pirá to fisheries depended on the type of fishing and site. Pirá was more important for artisanal fisheries than for sport fisheries, likely because it is more profitable to catch pirá using fishing nets, as employed by artisanal fishers, than by hook-and-line used by anglers.

Based on fishery data, the abundance of pirá at Três Marias seems lower than at fishing sites further downstream. Três Marias is located in the hyporhithron zone while Pirapora and Januária are in the epipotaman zone (Sato, Godinho, 2003). Thus, we suspect that pirá abundance might be related to environmental differences between these two zones.

Fishing gear and strategy may explain the smaller size of pirá captured by artisanal fishers at Buritizeiro compared to other sites. Cast nets with small stretched mesh size ( $\leq$ $11 \mathrm{~cm}$ ) were used in the shallow waters of the Buritizeiro Rapids. Other types of fishing gear, mainly cast nets with larger stretched mesh size $(\geq 12 \mathrm{~cm})$ and drift nets (stretched mesh size $\geq 14 \mathrm{~cm}$ ), were used in deeper waters, which are characteristic of the other sites.

Reproductive strategy. Pirá does not use floodplain lagoons as nursery grounds. Pirá, like other Neotropical migratory fishes, is pelagophilic, iteroparous and a groupsynchronous spawner (Godinho et al., 2010), with high fecundity and small, semi-buoyant free eggs that hatch in about $20 \mathrm{~h}$ (Sato et al., 2003a, 2003b). In general, Neotropical migratory fishes spawn in the rainy season during river floods (Godinho et al., 2010). Their eggs and larvae drift downstream towards floodplains, which are their most important nursery habitat (Sato, Godinho, 2003; Sato et al., 2003b; Godinho et al., 2010). However, pirá was only reported in one out of 60 floodplain lakes surveyed in the present study, which seems to indicate that it uses a different reproductive strategy.

We suspect that pirá does not spawn during floods and/or its early life stages drift near the bottom away from the river bank. Such adaptations would prevent them from reaching floodplain lakes, and instead lead them to a yet unknown nursery habitat within the river. This condition would not be unique to pirá, as there are, at least, three other Neotropical migratory catfishes - i.e., Brachyplatystoma rousseauxii and B. vaillantii (Barthem, Goulding, 1997) and Zungaro jahu (Agostinho et al., 2003), that do not use floodplain lakes as nursery habitats.
Conservation status. Pirá was first listed in the 2004 Brazilian red list as vulnerable before being categorized as endangered in 2014. Moreover, pirá was included as vulnerable in the 2010 red list of the state of Minas Gerais. Here, we evaluate the criteria used to list pirá in both red lists based on the data presented in the present study.

In the first Brazilian red list, which was prepared in 2002 and published in 2004 (Drummond, 2008), pirá was listed as vulnerable based on two IUCN criteria: 'A2ace' and 'B2ab(iii)' (Alves, Bockmann, 2008). The first criterion is applied when a population size reduction is $\geq 30 \%$ over the last 10 years (A2) based on direct observation (a), decline in area of occupancy (AOO), extent of occurrence (EOO) and/or quality of habitat (c), and effects of introduced taxa, hybridization, pathogens, pollutants, competitors or parasites (e). The second criterion is evoked when the AOO is estimated to be less than $2,000 \mathrm{~km}^{2}$ (B2) and estimates indicating AOO is severely fragmented or the species is known to exist at no more than 10 locations (a), and continuing decline, observed, inferred, or projected, in any area, extent and/or quality of habitat (b(iii)).

We found no evidence to support listing pirá in the 2004 Brazilian red list under the criterion 'A2ace'. The records from the Pirapora fishing boat are the only data available related to the pirá population size for the 10-year period prior to the elaboration of the list. The similar $C P U E_{n}$ for the years of 1987 and 1999 does not support a temporal reduction in population size of pirá. Moreover, our data do not support a decline in the $\mathrm{AOO}$ and/or EOO over the 10-year period prior to the elaboration of the red list. One might argue pirá could have been placed on the red list due to a decline in habitat quality, which most likely has indeed occurred. Brazil has given very little care to its rivers, and as a consequence habitat quality has declined in most of them, with the exception of those in the most remote areas. Thus, decline in habitat quality must be cautiously employed otherwise innumerous other Brazilian fishes would need to be included in the red list. The number of introduced taxa and pollutants have likely increased in the SFR basin in the years prior to the publication of the list (Alves et al., 2007), but there are no data available supporting their effects on pirá.

Pirá is not be eligible for listing as vulnerable in the 2004 Brazilian red list under the criterion 'B2ab(iii)'. To evoke this criterion, AOO should be less than 2,000 $\mathrm{km}^{2}$. Determining AOO is difficult for riverine fishes (Fagan et al., 2005; Mace et al., 2008). Since it is likely that pirá does not inhabit floodplains, we determined AOO as the length of the occupied river stretch multiplied by the average width of aquatic habitats along the river, as suggested by Fagan et al. (2005). In this case, AOO and EOO are equal. Although the AOO of pirá is less than $2,000 \mathrm{~km}^{2}$ (reach length occupied of $1,182 \mathrm{~km}$ multiplied by an average width of approximately $0.6 \mathrm{~km}$ ), it is not severely fragmented (there are no dams in the middle SFR, except at both ends of the stretch). In addition, the existing data do not support the continued decline of either AOO or EOO. Finally, decline in habitat quality must be used cautiously for the previously stated reasons. 
Still related to the inclusion of the pirá in the 2004 Brazilian red list, it remains to be determined whether the species was known to exist at no more than 10 locations. According to IUCN (2001), location is defined as a geographically or ecologically distinct area in which a single threatening event can rapidly affect all individuals of the taxon present. Moreover, the size of the location depends on the area covered by the threatening event (IUCN, 2001). The major threats to pirá, as mentioned by Alves, Bockmann (2008), are related to habitat quality, pollutants, introduced taxa and habitat fragmentation by hydropower dams. Alves, Bockmann (2008) did not mention using any of these threats to determine whether pirá was known to exist at no more than 10 locations. Moreover, the concept of location is more easily applied to species with very restricted distributions (ICMBio, 2013), which is not the case for pirá. Thus, determining the number of locations based on threats, like habitat quality, pollutants and introduced taxa, is not an easy task for pirá. This is not the case for hydropower dams, however, which can be used to determine the number of locations since pirá have virtually disappeared from the stretches of the SFR flooded by the reservoirs created by the hydropower dams.

At the time of the elaboration of the 2004 Brazilian red list, the Xingó Dam was the most recent hydropower dam to be built in the pirá AOO/EOO. There are still potential sites for the construction of dams in the SFR basin because its hydropower potential has yet to be fully exploited (Godinho, Loures, 2017). According to ANEEL (2018), there are 19 hydropower dams inventoried for the SFR basin, five of which are in the main course and within the AOO/EOO of pirá. Any dam inventoried for the pirá $\mathrm{AOO} / \mathrm{EOO}$ will only become a threat if construction is approved.

In the 2014 Brazilian red list (developed between 20102014), pirá was classified as endangered based on criterion 'A2cd' (ICMBio, 2018). The sub-criterion 'A2' is applied to classify species as endangered when a population size reduction is $\geq 50 \%$ over the last 10 years or 3 generations, whichever is the longest, based on decline in AOO, EOO and/or quality of habitat (c) and actual or potential levels of exploitation (d).

Pirá was included in the 2014 Brazilian red list because, at the time the list was developed, it was basically restricted to the middle SFR basin and exhibited a clear population reduction due to construction of dams and high fishing pressure (ICMBio, 2018). Moreover, since pirá was found in only $50 \%$ of its $\mathrm{AOO}$ and $\mathrm{EOO}$ at that time, it was estimated that its population size had experienced a reduction of $50 \%$ in the previous 30 years ( 3 generations), which happened at the same time as the construction of large dams in the lower SFR (ICMBio, 2018).

When the 2014 Brazilian red list was developed, the AOO and $\mathrm{EOO}$ of pirá had not been reduced by $50 \%$ or more. At that time, the $\mathrm{AOO}$ and $\mathrm{EOO}$ of pira were basically the 1,182 rkm of SFR between the Três Marias Dam and Sobradinho Reservoir, although on rare occasions pirá was captured upstream of Três Marias Dam and in the Sobradinho Reservoir.
Considering that pirá originally occurred throughout the entire main course of SFR, except most likely several tens of rkm of SFR headwaters, the AOO and EOO of 1,182 rkm represented about $42 \%$ of the length of the SFR. However, Sobradinho and Três Marias reservoirs were filled in 1978 and 1961, respectively (Brazilian Committee on Large Dams, s.d.), which happened 32 and 49 years before the beginning of the development of the 2014 Brazilian red list. Therefore, only the $1,932 \mathrm{rkm}$ of the SFR main course $(1,182 \mathrm{rkm}$ between Três Marias Dam and Sobradinho Reservoir plus the $750 \mathrm{rkm}$ of the sub-middle and lower regions) should have been considered in the analysis of the reduction in $\mathrm{AOO}$ and EOO in the development of the 2014 Brazilian red list. The construction of large dams in the lower SFR reduced the pirá $\mathrm{AOO}$ and $\mathrm{EOO}$ by $39 \%$ (corresponding to $750 \mathrm{rkm}$ of the $1,932 \mathrm{rkm}$ ), and not the $50 \%$ mentioned by ICMBio (2018). The percentage reduction in $\mathrm{AOO}$ and $\mathrm{EOO}$ were actually smaller because we did not include the major tributaries of the middle SFR inhabited by pirá in this latter analysis.

We are not aware of any study on age-structure of pirá, but we suspect the 10-year generation length (GL) used for including pirá in the 2014 Brazilian red list was an overestimate. Our concern is based on maximum age records for other large Brazilian freshwater fishes, which are: 6 years for Salminus brasiliensis (Tos et al., 2009), 8 years for Prochilodus lineatus (Santana, Minte-Vera, 2017) and Pseudoplastystoma reticulatum (Francisco et al., 2011) and 10 years for Arapaima gigas (Queiroz, 2000) and Pseudoplatystoma corruscans (Mateus, Petrere, 2004). Since the IUCN (2001) definition of generation length used for listing species in the 2014 Brazilian red list was the average age of parents of the current cohort, the 10 -year GL used for pirá is higher or equal to the maximum age reported for some other Brazilian large fish.

The guidelines in ICMBio (2013) were also used for listing species in the 2014 Brazilian red list. These guidelines suggested that GL can also be determined using the equation $\mathrm{GL}=$ age of $1^{\text {st }}$ maturation $+\mathrm{Z}$ (maximum age - age of $1^{\text {st }}$ maturation). None of these variables are known for pirá, so we used data available in the literature for other species as the best proxy to evaluate whether the GL of pirá could reach 10 years. The age of $1^{\text {st }}$ maturation is known for a small number of Brazilian medium-large freshwater fishes, which are: 1 year for Prochilodus brevis (Bomfim et al., 2015), 1-3 years for P. lineatus (Barbieri et al., 2004), 2-3 years for Salminus brasiliensis (Barbieri et al., 2004), 3 plus years for Brachyplatystoma rousseauxii (Garcia Vásquez et al., 2009) and 5 years for Arapaima gigas (Imbiriba, 2001). The two first species are smaller than pirá, but the last three are larger. Regarding Z, we are not aware of any Brazilian species for which $Z$ has already been determined. The IUCN home page for the red list of threatened species gives the value of $Z$ for only five fish species, all marine and of the class Actinopterygii (IUCN, 2018), the same class as pirá. For these species, $\mathrm{Z}$ ranged $0.15-0.50$. According to ICMBio (2013), $Z$ is normally less than 0.50. Abdul Malak et al. (2011) recommended using $\mathrm{Z}=0.50$ when $\mathrm{Z}$ is unknown. 
To calculate GL, we used maximum age $=10$ years (the highest value among the previously cited species), $Z=0.50$, and age of $1^{\text {st }}$ maturation ranging from 1 to 10 . Since GL is directly related to maximum age and $\mathrm{Z}$, the values we used for these two variables maximized GL.

We obtained GL values ranging from 5.5, for age of $1^{\text {st }}$ maturation $=1$, to 10.0 , for age of $1^{\text {st }}$ maturation $=10$. For each increment of 1 year in the age of $1^{\text {st }}$ maturation there was an increase of 0.5 year in GL. It is more likely that the age of $1^{\text {st }}$ maturation of pirá is less than 5 years than closer to 10 years because the smallest adult (gonads with macroscopic signs of gametogenesis) we captured $(35 \mathrm{~cm}$ for male and $43 \mathrm{~cm}$ for female) was just under half the size of the largest ones (79 $\mathrm{cm}$ for male and $92 \mathrm{~cm}$ for females). If the age of $1^{\text {st }}$ maturation for pirá is indeed less than 5 years, its GL would be $\leq 7$ years for a maximum age $=10$ years. If the maximum age is less than 10 years, which is most likely the case, the GL would be even smaller.

Moreover, for age of $1^{\text {st }}$ maturation $=5$ (the highest among the species mentioned above) and $\mathrm{Z}=0.5$, the maximum age will need to be 15 years in order for the GL of pirá to be 10 years. Since the maximum age for the other large Brazilian freshwater fishes mentioned above is 10 years, this also suggests that the GL of pirá is most likely less than 10 years.

In conclusion, in order for pirá to have a GL $\geq 10$ years, its age of $1^{\text {st }}$ maturation and maximum age would need to be greater than the age of $1^{\text {st }}$ maturation and maximum age known for other Brazilian fishes.

In the 2010 red list of the state of Minas Gerais, pirá was included as vulnerable under the 'B2ab(iii)c(ii)' IUCN criterion (Alves, Bockmann, 2008). This criterion is used when the AOO estimated to be less than $2,000 \mathrm{~km}^{2}$ (B2), associated to severely fragmented AOO or the species is known to exist at no more than 10 locations (a), and continuing decline, observed, inferred or projected, in area, extent and/or quality of habitat (b(iii)) and extreme fluctuations in AOO (c(ii)).

We found no evidence to support inclusion of pirá in the 2010 red list of the state of Minas Gerais. At the time the state red list was being developed, the AOO of pirá in Minas Gerais was likely less than $2,000 \mathrm{~km}^{2}$, even including the area of Três Marias Reservoir $\left(1,040 \mathrm{~km}^{2}\right)$. However, the sub-criterion 'a' was not applicable to pirá because only the most upstream portion of its habitat was fragmented by a dam (Três Marias Dam). The sub-criterion 'b(iii)' was also not pertinent to pirá because the most important decline in area, extent and/or quality of its habitat in Minas Gerais likely occurred during the formation of the Três Marias Reservoir back in the early 1960s, and no reservoir that could affect the habitat of pirá has been built since. Regarding the number of locations where the species is known to exist and decline of habitat quality, the same arguments used against adding pirá to the 2004 Brazilian red list are also applicable to its exclusion from the red list of the state of Minas Gerais. Finally, we found no evidence in our data, or elsewhere, showing extreme fluctuations in the $\mathrm{AOO}$ of pirá, as required by sub-criterion 'c(ii)'.
None of the three other IUCN criteria (i.e., C, D and E) used for listing species in the red list are appropriate for pirá. The criteria ' $C$ ' and ' $D$ ' require information on, at least, population size, while criterion ' $\mathrm{E}$ ' requires a quantitative analysis of the probability of extinction, neither of which are available for pirá.

\section{Acknowledgments}

We thank the Instituto Estadual de Florestas de Minas Gerais (IEF) and Instituto Brasileiro de Meio Ambiente e dos Recursos Naturais (IBAMA) for their support; Luiz Rocha, Marcelo Brito, Ana Paula G. Thé, Clube de Pesca Tangará, Colônia de Pescadores de Pirapora and Colônia de Pescadores de Januária for help with field work. We also thank the fishers who allowed and helped us to gather fishing data; and Paulo Henrique Fiote for the skillful drawing of pirá. We have no conflict of interest to declare. CNPq provided a research fellowship to ALG.

\section{References}

Abdul Malak D, Livingstone SR, Pollard D, Polidoro BA, Cuttelod A, Bariche $\mathrm{M}$ et al. Overview of the conservation status of the marine fishes of the Mediterranean Sea. Gland, Switzerland and Malaga, Spain: IUCN; 2011.

Agostinho AA, Gomes LC, Suzuki HI, Júlio HF Jr. Migratory fishes of the Upper Paraná River Basin, Brazil. In: Carolsfeld J, Harvey B, Ross C, Baer A, editors. Migratory fishes of South America. Victoria: World Fisheries Trust; 2003. p.21-98.

Agência Nacional de Energia Elétrica (ANEEL). Sistema de Informações Geográficas do Setor Elétrico. Brasília: ANEEL; 2018 [cited 2018 Jan 25]. Available from: http://sigel.aneel.gov. br/portal/home/index.html

Alves CBM, Bockmann FA. Conorhynchos conirostris (Valenciennes, 1840). In: Machado ABM, Drummond GM, Paglia AP, editors. Livro vermelho da fauna brasileira ameaçada de extinção, vol. 2. Brasília: Ministério do Meio Ambiente; Belo Horizonte: Biodiversitas; 2008. p.226-228.

Alves CBM, Vieira F, Magalhães ALB, Brito MF. Impacts of nonnative fish species in Minas Gerais, Brazil: present situation and prospects. In: Bert TM, editor. Ecological and genetic implications of aquaculture activities. Dordrecht: Springer; 2007. p.291-314.

Ayres M, Ayres Junior M, Ayres DL, Santos AS. Bioestat $5.0-$ Aplicações estatísticas nas áreas das ciências biomédicas. Belém: ONG Mamirauá; 2007.

Balon EK. Reproductive guilds of fishes: a proposal and definition. J Fish Res Board Can. 1975; 32(6):821-64.

Barbieri G, Salles FA, Cestarolli MA, Teixeira-Filho AR. Estratégias reprodutivas do dourado, Salminus maxillosus e do curimbatá, Prochilodus lineatus no Rio Mogi Guaçu, Estado de São Paulo, com ênfase nos parâmetros matemáticos da dinâmica populacional. Acta Sci Biol Sci. 2004; 26(2):169-74.

Barthem R, Goulding M. The catfish connection. New York: Columbia University Press; 1997. 
Bomfim AC, Peretti D, Camillo CS, Costa SAGL, Nascimento RSS. Reproductive biology and variations in the gonadal development of the fish Curimatã (Prochilodus brevis Steindachner, 1875) in captivity. Biota Amazônica. 2015; 5(2):65-70.

Brazilian Committee on Large Dams. Main Brazilian dams. São Paulo: Brazilian Committee on Large Dams, 1982.

Comitê Brasileiro de Grandes Barragens. Barragens do Brasil. N.1.: Comitê Brasileiro de Grande Barragens; 1982.

Drummond GM. Introdução. In: Machado ABM, Drummond GM, Paglia AP, editors. Livro vermelho da fauna brasileira ameaçada de extinção,vol. 1. Brasília: Ministério do Meio Ambiente; Belo Horizonte: Biodiversitas; 2008. p.39-42.

Fagan WF, Kennedy CM, Unmack PJ. Quantifying rarity, losses, and risks for native fishes of the lower Colorado River Basin: implications for conservation listing. Conserv Biol. 2005; 19(6):1872-82.

Francisco TM,Ambrósio AM, Balbi TJ,Zuliani MS, Okada EK, Gomes LC. Age and growth parameters of cachara Pseudoplastystoma reticulatum (Siluriformes, Pimelodidae) from the Cuiabá River, Brazil. Iheringia Ser Zool. 2011; 101(4):304-09.

Garcia Vásquez GA, Alonso JC, Carvajal F, Moreau J, Nuñez J, Renno JF, Tello S, Montreuil V, Duponchelle F. Life-history characteristics of the large Amazonian migratory catfish Brachyplatystoma rousseauxii in the Iquitos region, Peru. J Fish Biol. 2009; 75(10): 2527-51.

Godinho AL, Kynard B, Martinez CB. Supplemental water releases for fisheries restoration in a Brazilian floodplain river: a conceptual model. River Res Appl. 2007; 23(9):947-62.

Godinho AL, Lamas IR, Godinho HP. Reproductive ecology of Brazilian freshwater fishes. Environ Biol Fishes. 2010; 87(2):143-62.

Godinho AL, Loures RC. Risk of fish death at Brazilian hydropower plants. In: Loures RC, Godinho AL, editors. Risk assessment of fish death at hydropower plants in southeastern Brazil. Belo Horizonte: Companhia Energética de Minas Gerais; 2017. p.19-36.

Godinho HP, Miranda MOT, Godinho AL, Santos JE. Pesca e biologia do surubim Pseudoplatystoma coruscans no rio São Francisco. In: Miranda MOT, editor. Surubim. Belo Horizonte: IBAMA; 1997. p.27-42.

Imbiriba EP. Potencial de criacão de pirarucu, Arapaima gigas, em cativeiro. Acta Amaz. 2001; 31:299-316.

Instituto Chico Mendes de Conservação da Biodiversidade (ICMBio). Aplicação de Critérios e Categorias da UICN na Avaliação da Fauna Brasileira. S.1.: ICMBio, 2013.

Instituto Chico Mendes de Conservação da Biodiversidade (ICMBio). Peixes - Conorhynchos conirostris (Valenciennes, 1840) - Pirátamanduá. Brasília: Instituto Chico Mendes de Conservação da Biodiversidade; 2018 [cited 2018 Jan 1]. Available from: http:// www.icmbio.gov.br/portal/faunabrasileira/lista-de-especies/6237especie-6237

Instituto Xingó. Recomposição da ictiofauna reofílica do baixo São Francisco. Canindé do São Francisco: Instituto Xingó; 2003.

International Union for Conservation of Nature (IUCN). IUCN Red List categories and criteria: Version 3.1. Gland: IUCN; 2001.

International Union for Conservation of Nature (IUCN). The IUCN Red List of threatened species. Gland: IUCN; 2018 [cited 2018 Jan 22]. Available from: http://www.iucnredlist.org/
Mace GM, Collar NJ, Gaston KJ, Hilton-Taylor C, Akçakaya HR, Leader-Williams et al. Quantification of extinction risk: IUCN's system for classifying threatened species. Conserv Biol. 2008; 22(6):1424-42.

Mateus LAF, Petrere M Jr. Age, growth and yield per recruit analysis of the pintado Pseudoplatystoma corruscans (Agassiz, 1829) in the Cuiabá River basin, Pantanal Matogrossense, Brazil. Braz J Biol. 2004; 64(2):257-64.

Prado IG, Andrade FR, Souza RCR, Monteiro AB, Godinho AL. The arribação in the upper-middle São Francisco River, Brazil. In: Loures RC, Godinho AL, editors. Risk assessment of fish death at hydropower plants in southeastern Brazil. Belo Horizonte: Cemig; 2017. p.259-272.

Queiroz HLD. Natural history and conservation of pirarucu, 'Arapaima gigas', at the Amazonian Várzea: red giants in muddy waters. [PhD Thesis] St Andrews: University of St Andrews, 2000.

Santana HS, Minte-Vera CV. Age and growth of Prochilodus lineatus in a spatially structured population: is there concordance between otoliths and scales? Environ Biol Fishes. 2017; 100(3):223-35.

Sato Y. Reprodução de peixes da bacia do rio São Francisco: indução e caracterização de padrões. [PhD Thesis]. São Carlos: Universidade Federal de São Carlos; 1999.

Sato Y, Fenerich-Verani N, Godinho HP. Reprodução induzida de peixes da bacia do São Francisco. In: Godinho HP, Godinho AL, editors. Águas, peixes e pescadores do São Francisco das Minas Gerais. Belo Horizonte: PUC Minas; 2003a. p.275-89.

Sato Y, Fenerich-Verani N, Nuñer APO, Godinho HP, Verani JR. Padrões reprodutivos de peixes da bacia do São Francisco. In: Godinho HP, Godinho AL, editors. Águas, peixes e pescadores do São Francisco das Minas Gerais. Belo Horizonte: PUC Minas; 2003b. p.229-274.

Sato Y, Godinho HP. Migratory fishes of the São Francisco River. In: Carolsfeld J, Harvey B, Ross C, Baer A, editors. Migratory fishes of South America. World Fisheries Trust, Victoria; 2003. p.195232.

Silva PA, Vieira GG, Farinasso M, Carlos RJ. Determinação da extensão do rio São Francisco. In: Instituto de Pesquisas Espaciais, editor. Simpósio Brasileiro de Sensoriamento Remoto 2003. São José dos Campos: Instituto de Pesquisas Espaciais; 2003. p.393-400.

Superintendência de Desenvolvimento da Pesca, Companhia de Desenvolvimento do Vale do rio São Francisco (SDP, CODEVASF). Diagnóstico da pesca no vale do rio São Francisco. Brasília: Superintendência de Desenvolvimento da Pesca, Companhia de Desenvolvimento do Vale do rio São Francisco; 1980.

Tos CD, Gomes LC, Agostinho AA, Batista RP. Age, growth, mortality and yield per recruit of the dourado Salminus brasiliensis, Corumbá Reservoir, Goiás State, Brazil. Neotrop Ichthyol. 2009; 7(2):223-30. 